\title{
Differing Contribution of Polymorphonuclear Cells and Macrophages to Protection of Mice against Listeria monocytogenes and Pseudomonas aeruginosa
}

\author{
By KEIJI TATSUKAWA, MASAO MITSUYAMA, KENJI TAKEYA \\ AND KIKUO NOMOTO \\ Departments of Microbiology and Immunology, School of Medicine, Kyushu University, \\ Higashi-ku, Fukuoka, 812 Japan
}

(Received 27 December 1978; revised 17 April 1979)

Bacterial growth and lethality of Listeria monocytogenes in mice were augmented by carrageenan-treatment and $\mathrm{X}$-irradiation $\left(8 \mathrm{~J} \mathrm{~kg}^{-1}\right)$, whereas growth and lethality of Pseudomonas aeruginosa were augmented by $\mathrm{X}$-irradiation but not by carrageenan-treatment. Protection against $L$. monocytogenes, at least in the early phases, appears to depend mainly on macrophages, since carrageenan depletes macrophages but not polymorphonuclear cells (PMN), whereas protection against $P$. aeruginosa appears to depend mainly on PMN. Ineffectiveness of PMN in elimination of $L$. monocytogenes is supported by histological examination and observation of intracellular killing in vitro.

\section{INTRODUCTION}

Phagocytes, including polymorphonuclear cells (PMN) and monocytes or macrophages, are the final effector cells in the elimination from animals of a variety of bacteria and fungi. Many kinds of micro-organism are therefore able to produce severe infections in hosts whose phagocyte functions are depressed artificially by X-irradiation (Kaplan et al., 1952; Gordee \& Simpson, 1967), cyclophosphamide (Sharbaugh \& Grogan, 1969; Tripathy \& Mackaness, 1969; Buhles \& Shifrine, 1977), vinblastine (Tripathy \& Mackaness, 1969) or vincristine (Saslaw et al., 1972). Such agents depress PMN, macrophages and lymphocytes, so that one cannot reach any conclusions as to which cells protect against individual microorganisms. Even in systems in which immunological mechanisms can be excluded, the relative contributions of PMN and macrophages to protection remain to be analysed.

In the present study, Listeria monocytogenes and Pseudomonas aeruginosa were chosen as a facultative intracellular parasite and an extracellular parasite, respectively. Limitation of bacterial growth in early phases of infection with $L$. monocytogenes has been proved in our laboratory to be mainly the function of non-immune phagocytes (Mitsuyama et al., 1978). Cellular immunity appears not to be important in protection against $P$. aeruginosa (Reynolds, 1974). To analyse the differing contributions of PMN and macrophages to protection, X-irradiation was used to deplete the total population of phagocytes and carrageenan was used to deplete selectively cells of the macrophage series (Catanzaro et al., 1971).

\section{METHODS}

Animals. Female and male mice ( 8 to 12 weeks old) of an outbred ddN strain were obtained from the Breeding Unit of Experimental Animals, Kyushu University.

Micro-organisms. Listeria monocytogenes strain EGD was donated by Dr. Ishibashi, Research Institute for Diseases of the Chest, School of Medicine, Kyushu University. Pseudomonas aeruginosa was isolated 
from the sputum of a patient suffering from acute pneumonia. The bacteria were maintained by serial passage in ddN mice before use in this study. Fresh isolates were obtained from spleens, subcultured once on Tryptic Soy Agar (Difco) and used for infection. The $\mathrm{LD}_{50}$ by the intravenous route of $L$. monocytogenes was approximately $8 \times 10^{4}$ viable bacteria and that of $P$. aeruginosa approximately $1 \times 10^{7}$.

Count of peripheral leukocytes. Blood specimens were collected by puncture of the retro-orbital venous plexus. Total numbers of leukocytes were counted after staining with Türk's solution and differential counts were carried out after staining of smears with Giemsa's solution.

Carbon clearance test. Colloidal carbon c11/1431a (Günther-Wagner, Pelikan-Werke, Hanover, FRG; $16 \mathrm{mg} \mathrm{kg}^{-1}$ ) was injected intravenously and blood specimens were obtained at $3 \mathrm{~min}$ intervals for $15 \mathrm{~min}$. The phagocytic index, $\mathrm{K}_{16}$, was calculated from the pattern of disappearance of carbon from the blood by the Biozzi method (Stuart et al., 1973).

Determination of bacterial growth. Mice were inoculated intravenously with $4 \times 10^{3}$ viable $L$. monocytogenes or $1 \times 10^{4}$ viable $P$. aeruginosa suspended in Hanks' balanced salt solution (HESS; Paul, 1973). At various times after inoculation, they were bled by cutting the femoral artery, and their livers and spleens were removed. Individual organs were homogenized separately in $10 \mathrm{ml}$ phosphate-buffered saline (PBS; Paul, 1973) with Teflon homogenizers. The homogenized suspensions were serially diluted 10 fold with PBS and $0.1 \mathrm{ml}$ of each dilution was spread on nutrient agar containing $0.3 \%(\mathrm{w} / \mathrm{v})$ glucose. Three plates were prepared for each dilution of each specimen. Colonies were counted after incubation at $37^{\circ} \mathrm{C}$ for $20 \mathrm{~h}$. To observe bacterial growth in a local infection, bacterial suspensions were inoculated intramuscularly into the middle of the right thigh. The whole mass of the muscle of an infected thigh was removed and treated in the same way as described for the estimation of bacterial growth in the liver and spleen.

$X$-irradiation. Mice were exposed to $8 \mathrm{~J} \mathrm{~kg}^{-1}(800 \mathrm{rad})$ of whole body X-irradiation and infected $2 \mathrm{~d}$ later. The radiation was delivered from a Shimadzu $250 \mathrm{kV}$ machine (Shimadzu, K.K., Tokyo, Japan) operating

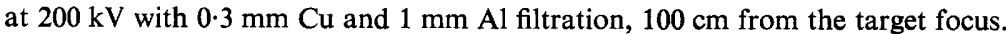

Carrageenan. Carrageenan type II (Sigma) was dissolved in distilled water and injected intraperitoneally (200 $\mathrm{mg} \mathrm{kg}^{-1}$ ) $24 \mathrm{~h}$ before infection.

Preparation of PMN and macrophages. PMN were washed out of the peritoneal cavity with HBSS $3 \mathrm{~h}$ after injection of $2 \mathrm{ml} 0.2 \%(\mathrm{w} / \mathrm{v})$ sodium caseinate. The suspension contained about $80 \%$ PMN. Macrophages were harvested similarly $4 \mathrm{~d}$ after injection of $2 \mathrm{ml} 2.4 \%$ (w/v) thioglycollate medium (Difco). Approximately $65 \%$ of the cells were macrophages. In the experiment assessing the function of carrageenantreated PMN, peritoneal exudate cells were washed out from carrageenan-treated mice $16 \mathrm{~h}$ after injection of thioglycollate medium. To eliminate macrophages that had ingested carrageenan the cells were layered gently on Ficoll-Conray solution (Böyu $\mathrm{n}, 1968$ ) and the cell pellet was harvested by centrifugation at $400 \mathrm{~g}$ for $30 \mathrm{~min}$.

Phagocytosis and intracellular killing in vitro. Cell suspensions were washed three times with HBSS and resuspended at $2 \times 10^{7}$ cells $\mathrm{ml}^{-1}$ in HBSS containing $0.1 \%(\mathrm{w} / \mathrm{v})$ gelatin and $10 \%(\mathrm{v} / \mathrm{v})$ fresh autologous serum. The viability of suspended cells was over $95 \%$. Cell suspensions $(2.5 \mathrm{ml})$ were mixed with equal volumes of bacterial suspensions containing $2 \times 10^{7}$ bacteria $\mathrm{ml}^{-1}$ and incubated at $37^{\circ} \mathrm{C}$ for 15 min to allow phagocytosis to occur. The mixtures were then centrifuged repeatedly to remove free bacteria. Cells were disrupted with sodium dodecyl sulphate (SDS ; $0.1 \%$ final concn) for $1 \mathrm{~min}$ at room temperature and bacteria in the suspensions were counted. In order to observe the rate of intracellular killing, washed cell suspensions were incubated further after phagocytosis as described above. The numbers of bacteria remaining viable within cells were determined by culture on nutrient agar after disrupting the cells wih SDS at appropriate times.

Histology. Listeria monocytogenes $\left(2 \times 10^{6}\right)$ or $P$. aeruginosa $\left(1 \times 10^{6}\right)$ were inoculated intramuscularly into the right thigh and the infected muscle was removed 6,24 or $72 \mathrm{~h}$ later. Sections were stained with Giemsa's solution and infiltrating cells were observed.

RESULTS

Effects of carrageenan

Numbers of PMN and macrophages (monocytes) in the peripheral blood were counted at intervals after mice had been treated with carrageenan (Fig. 1). The number of PMN increased approximately fourfold by 1 or $2 \mathrm{~d}$ after treatment compared with untreated controls and then decreased slowly to reach the control level by day 15 . The number of macrophages decreased eightfold by day 2 and then increased slowly to reach the control level by day 15 .

To observe the effect of carrageenan on the function of fixed macrophages, the rate of 


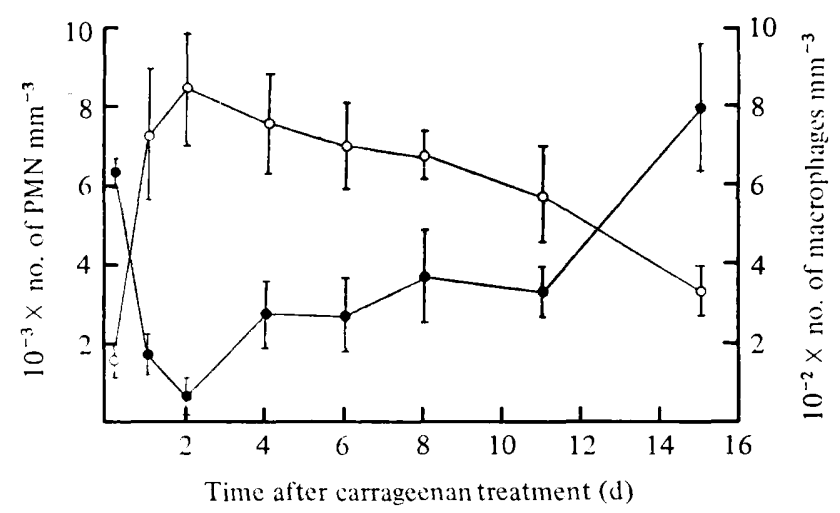

Fig. 1. Effect of carrageenan on the number of PMN $(\bigcirc)$ and macrophages $(O)$ in the peripheral blood. Carrageenan was injected intraperitoneally $\left(200 \mathrm{mg} \mathrm{kg}^{-1}\right)$ on day 0 . Each point and bar indicates the mean number for four mice \pm S.D.

carbon clearance was estimated after treatment. The phagocytic index $\left(\mathrm{K}_{16}\right)$ was $0.035 \pm$ S.D. 0.006 before treatment but decreased to $0.013 \pm 0.003$ at $1 \mathrm{~d}$ and increased slowly thereafter. The inhibition of carbon clearance lasted for $7 \mathrm{~d}$. From these results, it seemed likely that carrageenan decreased or impaired cells of the macrophage series.

In order to evaluate the function of PMN in carrageenan-treated mice, the capacity to kill $P$. aeruginosa was estimated in vitro. Killing by untreated PMN was $1 \cdot 31 \pm 0 \cdot 12$ expressed as $\log _{10}$ (proportional decrease in number of viable bacteria) in $30 \mathrm{~min}$, while that by carrageenan-treated PMN was $1 \cdot 30 \pm 0 \cdot 38$. Thus, the capacity of PMN in treated mice was comparable to that in normal controls. These results suggested that carrageenan mainly affected macrophages and not PMN.

\section{Mortality rate after bacterial infection in carrageenan-treated mice and X-irradiated mice}

Mice showed large decreases in the numbers of PMN and macrophages at $2 \mathrm{~d}$ after exposure to whole body irradiation (results not shown). Lethal effects after intravenous inoculation of $8 \times 10^{3} \mathrm{~L}$. monocytogenes or $2 \times 10^{4} \mathrm{P}$. aeruginosa were compared among carrageenan-treated, $X$-irradiated and untreated control groups. Such doses were not lethal to untreated mice (Fig. 2). After inoculation with L. monocytogenes, all carrageenan-treated and $\mathrm{X}$-irradiated mice died within $8 \mathrm{~d}$. All $\mathrm{X}$-irradiated mice died within $4 \mathrm{~d}$ after inoculation with $P$. aeruginosa, while $67 \%$ of carrageenan-treated mice survived beyond 2 weeks.

\section{Bacterial growth in organs after intravenous inoculation}

Numbers of viable bacteria in the liver and spleen were determined 1,2 and $3 \mathrm{~d}$ after intravenous inoculation with $4 \times 10^{3} \mathrm{~L}$, monocytogenes. Recoveries of bacteria from the livers on day 1 ranged from $2 \times 10^{4}$ to $9 \times 10^{4}$ showing no significant differences among controls, carrageenan-treated mice and X-irradiated mice. At day 3 , the number was approximately $10^{5}$ in untreated controls, but reached $5 \times 10^{7}$ or more in the carrageenantreated and $\mathrm{X}$-irradiated groups. Similar patterns of bacterial growth were observed in the spleen.

Numbers of bacteria in the liver, spleen and blood were determined 4,50 and $80 \mathrm{~h}$ after intravenous inoculation of $1 \times 10^{4} P$. aeruginosa. Control mice and carrageenan-treated mice cleared their blood of bacteria by $4 \mathrm{~h}$ and their livers and spleens showed no bacterial growth at 50 or $80 \mathrm{~h}$ after inoculation. Large numbers of bacteria (over $10^{5}$ ) were recovered from some X-irradiated mice. 


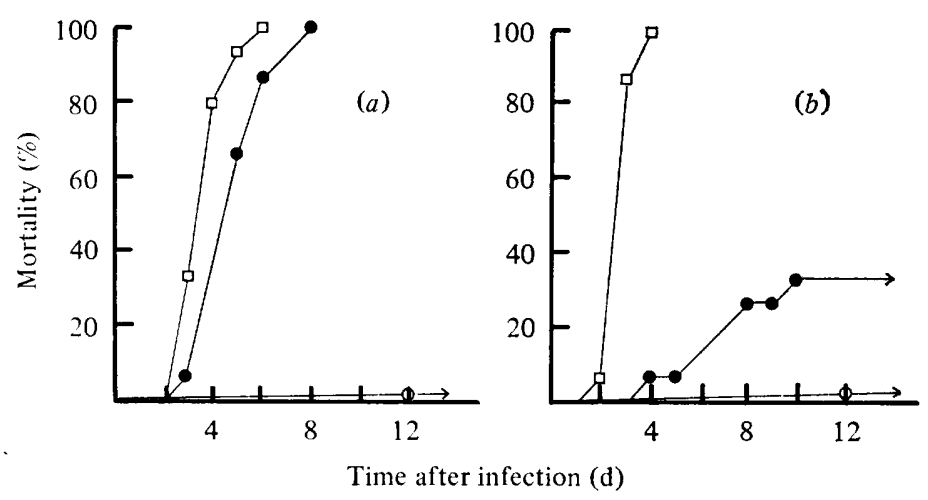

Fig. 2. Mortality after intravenous challenge of (a) $8 \times 10^{3} \mathrm{~L}$. monocytogenes and (b) $2 \times 10^{4}$ $P$. aeruginosa. $\bigcirc$, Control mice; $\bullet$, carrageenan-treated mice; $\square, \mathrm{X}$-irradiated mice.

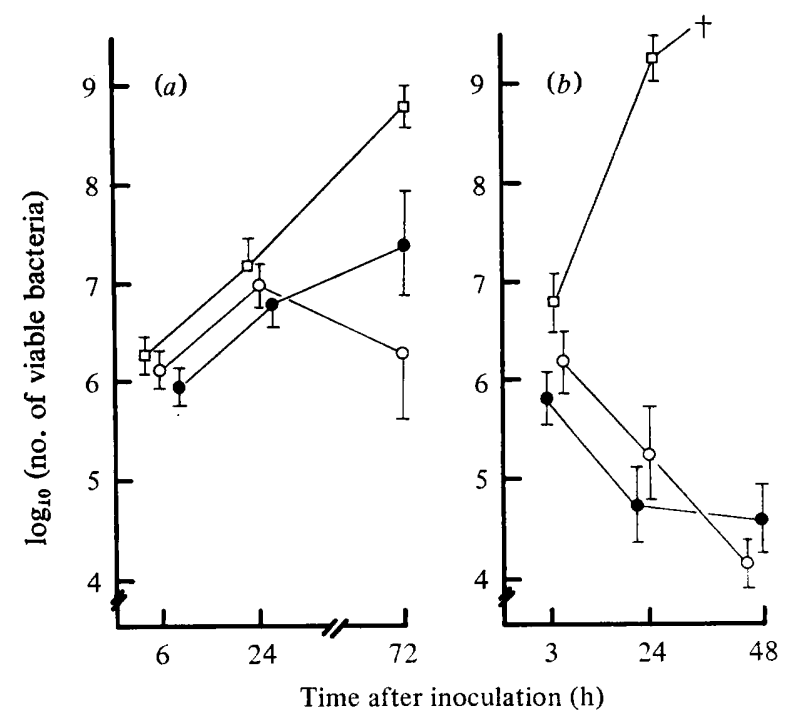

Fig. 3. Bacterial growth in the muscle after intramuscular inoculation of $(a) 1 \cdot 0 \times 10^{6} \mathrm{~L}$. monocytogenes and $(b) 8.5 \times 10^{6} P$. aeruginosa. $\bigcirc$, Control mice; carrageenan-treated mice; $\square$, X-irradiated mice.

\section{Bacterial growth after intramuscular inoculation}

Local proliferation of bacteria was observed after intramuscular inoculation into the thighs of carrageenan-treated mice, $X$-irradiated mice and untreated controls. When $1 \times 10^{6} \mathrm{~L}$. monocytogenes were inoculated into controls, the number of bacteria increased slightly by $24 \mathrm{~h}$ and then decreased to about $10^{6}$ by $72 \mathrm{~h}$ (Fig. 3). The numbers of bacteria increased progressively from $6 \mathrm{~h}$ to $72 \mathrm{~h}$ in carrageenan-treated mice and $\mathrm{X}$-irradiated mice, although the degree of increase was higher in the latter than in the former.

When $8.5 \times 10^{6} P$. aeruginosa were inoculated into untreated controls, the number decreased progressively from $3 \mathrm{~h}$ to $48 \mathrm{~h}$ to reach around $10^{4}$. In carrageenan-treated mice, the number decreased similarly. On the other hand, the number increased progressively and extensively from $3 \mathrm{~h}$ to $24 \mathrm{~h}$ in $\mathrm{X}$-irradiated mice; none of these mice survived $48 \mathrm{~h}$ after infection. 


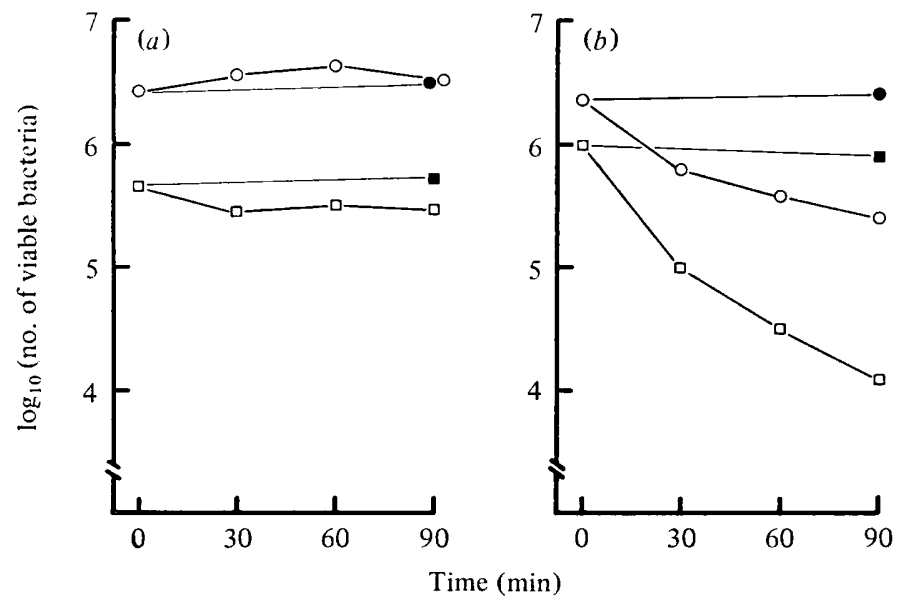

Fig. 4. Phagocytosis and intracellular killing of (a) L. monocytogenes and (b) P. aeruginosa by macrophages and PMN in vitro. The number of viable bacteria at 0 min represents phagocytized bacteria after 15 min preincubation (see Methods). $\bigcirc$, Macrophages incubated at $37^{\circ} \mathrm{C}$;, macrophages at $0{ }^{\circ} \mathrm{C} ; \square \mathrm{PMN}$ at $37^{\circ} \mathrm{C} ; \mathbf{\square}, \mathrm{PMN}$ at $0^{\circ} \mathrm{C}$.

\section{Histological examination of cellular infiltration into infected sites}

Considerable infiltration of PMN was detected $6 \mathrm{~h}$ after inoculation with $L$. monocytogenes or P. aeruginosa and PMN comprised approximately $80 \%$ of infiltrating cells at $24 \mathrm{~h}$. The proportion of macrophages or lymphocytes increased slightly thereafter. At $72 \mathrm{~h}$ after inoculation with $P$. aeruginosa, the absolute number of infiltrating cells decreased compared with earlier phases and macrophages and lymphocytes increased relatively. At $72 \mathrm{~h}$ after inoculation with L. monocytogenes, on the other hand, the absolute number of infiltrating cells increased compared with earlier phases. Considerable numbers of macrophages were detected in such lesions.

\section{Phagocytosis and intracellular killing of bacteria in vitro}

Listeria monocytogenes was phagocytized efficiently by macrophages, but the degree of phagocytosis by PMN was about 10-fold lower than by macrophages. Intracellular killing was scarcely detected in macrophages or in PMN (Fig. 4). Pseudomonas aeruginosa was phagocytized and killed efficiently by PMN and macrophages, although the efficiency of intracellular killing was slightly higher in PMN than in macrophages.

\section{DISCUSSION}

The number of PMN increased considerably after carrageenan injection and their capacity to kill $P$. aeruginosa was retained normally. The number of macrophages and rate of carbon clearance decreased in such carrageenan-treated mice and so these animals may be tentatively regarded as macrophage-depleted. The numbers of PMN and macrophages decreased strikingly in X-irradiated mice, which may therefore be regarded as PMN- and macrophagedepleted animals.

Mortality after inoculation of a sublethal dose of either L. monocytogenes or P. aeruginosa was markedly augmented by $\mathrm{X}$-irradiation. Carrageenan-treatment increased the lethal effect of $L$. monocytogenes but only slightly augmented that of $P$. aeruginosa. Bacterial growth after systemic or local infection with $L$. monocytogenes was enhanced in both carrageenan-treated mice and $\mathrm{X}$-irradiated mice. Bacterial growth of $\boldsymbol{P}$. aeruginosa was enhanced in X-irradiated mice, but not in carrageenan-treated mice. These results suggest that 
in vivo protection against $P$. aeruginosa depends mainly on PMN whereas that against $L$. monocytogenes depends mainly on macrophages.

Polymorphonuclear cell infiltration became detectable within a few hours after inoculation with $L$. monocytogenes and $P$. aeruginosa. The latter started to decrease in number at this stage, but $L$. monocytogenes continued to increase until $24 \mathrm{~h}$ in the presence of PMN accumulation. This supports the tentative conclusion that PMN are effective in elimination of $P$. aeruginosa but not of $L$. monocytogenes. One reason for ineffectiveness of PMN in eliminating L. monocytogenes may be the low degree of phagocytosis observed in vitro.

Macrophages may also contribute to elimination of $P$. aeruginosa, but PMN can protect efficiently against $P$. aeruginosa by their rapid accumulation at infected sites even in the absence of macrophages. It is possible that macrophages eliminate $P$. aeruginosa in the absence of normally functioning PMN. This is supported by the fact that prior stimulation with complete Freund's adjuvant or BCG increased the lethal dose of $P$. aeruginosa for mice treated with cyclophosphamide (Buhles \& Shifrine, 1977). Complete Freund's adjuvant or BCG has been reported to stimulate macrophage function (Blanden, 1968; Gentry \& Remington, 1971).

The rates of phagocytosis and intracellular killing of $L$. monocytogenes by macrophages in vitro were shown to be slower than those by PMN in experiments with human cells (Steigbigel et al., 1974; Peterson et al., 1977). The difference in effectiveness of PMN in resistance against $L$. monocytogenes as observed in their and in our experiments may be due to different functions of cells in different host species.

This work was supported by Grant-in-Aid from the Ministry of Education, Science and Culture and the Ministry of Health and Welfare, Japan.

\section{REFERENCES}

BLANDEN, R. V. (1968). Modification of macrophage function. Journal of the Reticuloendothelial Society 5, 179-202.

Böyum, A. (1968). Separation of leukocytes from blood and bone marrow. Scandinavian Journal of Clinical and Laboratory Investigation 21, Suppl. 97, 77-88.

BuHles, W. C. \& Shifrine, M. (1977). Adjuvant protection against bacterial infection in granulocytopenic mice. Journal of Infectious Diseases 136, 90-95.

Catanzaro, P. J., Schwartz, H. J. \& Graham, R. C. (1971). Spectrum and possible mechanism of carrageenan cytotoxicity. American Journal of Pathology 64, 387-404.

Gentry, L. O. \& Remington, J. S. (1971). Resistance against Cryptococcus conferred by intracellular bacteria and protozoa. Journal of Bacteriology 94, 6-12.

GoRdEE, R. S. \& Simpson, P. J. (1967). Relationships of X-irradiation to the enhancement of Candida albicans infections. Journal of Bacteriology 94, 6-12.

Kaplan, H.S., SPeCK, R. S. \& Jawetz, E. (1952). Impairment of antimicrobial defences following total body irradiation of mice. Journal of Laboratory and Clinical Medicine 40, 682-691.

Mitsuyama, M., Takeya, K., Nomoto, K. \& Shimotori, S. (1978). Three phases of phagocyte contribution to resistance against Listeria monocytogenes. Journal of General Microbiology 106, 165-171.
Paul, J. (1973). Cell and Tissue Culture, 4th edn. Edinburgh: Churchill Livingstone.

Peterson, P. K., Verhoef, J., Schmeling, D. \& Quie, P. G. (1977). Kinetics of phagocytosis and bacterial killing by human polymorphonuclear leukocytes and monocytes. Journal of Infectious Diseases 136, 502-509.

REYNolds, H. Y. (1974). Pulmonary host defenses in rabbits after immunization with Pseudomonas antigens: the interaction of bacteria, antibodies, macrophages and lymphocytes. Journal of Infectious Diseases 130, Suppl. 134-142.

Saslaw, S., Carlisle, H. N. \& Moheiman, M. (1972). Effect of vincristine sulfate on Pseudomonas infections in monkeys. Infection and Immunity 6, 149-155.

Sharbaugh, R. J. \& Grogan, J. B. (1969). Effect of cyclophosphamide on experimental staphylococcus infection in the rat. Nature, London 224, 809-810.

Steigbigel, R. T., LAmbert, L. H. \& Remington, J. S. (1974). Phagocytic and bactericidal properties of normal human monocytes. Journal of Clinical Investigation 53, 131-142.

Stuart, A. E., Habeshaw, J. A. \& Davidson, A. E. (1973). In Handbook of Experimental Immunology, 2nd edn, ch. 24. Edited by D. M. Weir. Oxford: Blackwell Scientific Publications.

Tripathy, S. P. \& Mackaness, G. B. (1969). The effect of cytotoxic agents on the primary immune response to Listeria monocytogenes. Journal of Experimental Medicine 130, 1-16. 